\title{
Pembiakan Cacing Tanah Perionyx Excavatus Dengan Teknik Vermikultur Limbah Peternakan Dan Pengaruhnya TerhadapPupuk Kandang Yang Dihasilkan
}

\author{
Yumaihana \\ Jurusan Nutrisi Makanan Ternak Fakultas Peternakan Universitas Andalas, Padang
}

\begin{abstract}
The life cycle of earthworm Perionyx excavatus in the faces of livestock animals has been studied and had potency to depredate the animal wastes through vermiculture process. Optimal live environmental conditions were needed to achieve the optimal vermiculture process. The rate of growth and reproduction of the worm depended mainly on the availability of nutrition in the medium. In this experiment, four different animal feces were used as vermiculture media, e.g. cattle, horse, rabbit and chicken. The increase of body length was measured as the growth rate function of the worm P. excavagatus. The change of temperature, $\mathrm{pH}$ and humidity of medium were measured as the factors affecting the growth rate. These factors were important in research objectives, i.e. production of earthworm biomass for poultry feedstuff and of high quality biofertilizer by using animal wastes as vermiculture medium. Feces of cattle and rabbit were found the best medium of vermiculture. P.excavagus cultivated in the feces of both animals showed the fast similar growth rate. The growth rate of P.excavagus in four different medium could be ordered as follows: cattle feces $\geq$ rabbit feces $>$ horse feces. Feces of chicken was found not suitable for earthworm media because of low $\mathrm{pH}$. Biofertilizer from the vermiculture could be produced in relatively short time period with better physical characteristic in compare to the normal biofertilizer.
\end{abstract}

Key words: earthworm P. excavagatus, biofertilizer, vermiculture process.

\section{Pendahuluan}

Cacing tanah merupakan organisme yang memiliki potensi sangat besar dalam kehidupannya. Pada studi literatur telah diketahui manfaat cacing tanah dalam ilmu pengobatan dan pangan. Masyarakat cina telah lama menggunakan cacing tanah sebagai obat tradisional, sementara di Indonesia juga telah dimanfaatkan untuk mengobati demam tifoid dan stroke. Bahkan di Jepang, Hongaria, Thailand, Filipina dan Amerika Serikat selain untuk pengobatan dan bahan kosmetik, sebagian masyarakatnya menjadikan tepung cacing tanah sebagai bahan makanan manusia. Protein yang terdapat dalam cacing tanah mengandung asam amino esensial yang kualitasnya melebihi ikan dan daging (Sajuthi, et, al, 2003). Dari analisis kandungan nitrogen kasar, 58 sampai $78 \%$ dari bobot kering cacing tanah adalah protein. Selain itu cacing tanah diketahui rendah lemak hanya 3 sampai 10 persen dari bobot keringnya. Berdasarkan data tersebut caing tanah sangat potensial sebagai pakan ternak dan aman untuk dikonsumsi.

Cacing tanah jenis Perionyx excavatus merupakan hewan pengurai yang hidup di bawah tumpukan daun gugur dan tempat tempat lain yang lembab. Memiliki kemampuan untuk mendegradasi 
senyawa organik yang kompleks menjadi lebih sederhana sehingga dapat dimanfaatkan organisme lain. $P$. excavatus merupakan cacing tanah yang banyak terdapat di daerah tropis.

Vermikultur adalah pembiakan cacing dengan menggunakan media tumbuh yang cocok. Tanah hasil penguraian disebut kascing atau pupuk kandang. Teknik ini sederhana dan bisa untuk mengolah limbah peternakan. Beberapa faktor seperti suhu lingkungan, kelembaban, cahaya matahari dan hewan pengganggu perlu diperhatikan untuk mendapatkan reproduksi dan pertumbuhan yang maksimum. Variasi kotoran sebagai media bisa mempengaruhi pertumbuhan cacing tanah terutama $P$. excavatus. Hal ini menyangkut pada kenyamanan terhadap senyawa buangan pada kotoran dan juga kemampuan dalam mengantisipasi bakteri yang ada dalam kotoran tersebut. Namun sistem kekebalan tubuh cacing yang sangat kompleks dan sangat mendukung bisa menjadi nilai tambah dalam penguraian kotoran menjadi pupuk organik dalam waktu relatif lebih pendek dibanding dengan fermentasi.

Berdasarkan penelitian pendahuluan, diketahui bahwa $P$. excavatus memiliki sifat anti bakteri terhadap beberapa spesies (bakteri) disamping kandungan proteinnya yang tinggi. Penelitian lanjutan perlu dilakukan dan dikembangkan. Saat ini penelitian difokuskan pada pembiakan cacing tanah sebagai sumber pakan unggas dengan memanfaatkan kotoran ternak sebagai media vermikultur dan melihat pengaruh penguraian kotoran oleh cacing tanah terhadap mutu pupuk organik sebagai hasil ikutan.

\section{Materi dan Metode}

\section{Materi Penelitian}

Cacing tanah Perionyx excavatus dari CV Osa Perdana, Bandung.

\section{Alat - alat}

Baskom - baskom plastik ukuran besar untuk membiakkan tanah, sekop untuk mengatur aerasi media, autoclave, tabung reaksi, sarung tangan, masker, cawan patri, jarum ose, bunsen untuk menjaga lingkungan steril, $\mathrm{pH}$ meter untuk mengatur $\mathrm{pH}$ media, termometer untuk mengatur suhu.

2. Bahan Kimia

\section{Bahan}

$$
\text { kimia }
$$
dipergunakan dalam penelitian ini mempunyai kualitas proanalisis (pa) kecuali disebutkan lain, yaitu Tripton bakto, agar bakto, yeast (elatrak ragi), $\mathrm{NaCl}$, aquades babas ion dan steril, aquabides, ethanol, $\mathrm{Na}_{2} \mathrm{CO}_{3}$, $\mathrm{NaOH}, \mathrm{CuSO}_{4}$, Na-tartrat.

\section{Metode Penelitian}

Metode penelitian menggunakan cacing yang sudah dewasa dengan perlakukan variasi lama pergantian media $1,4,7,10,16,19$ hari. Peubah yang diamati adalah kecepatan pertumbuhan cacing, $\mathrm{pH}$ kotoran dan pupuk kandang hasil penguraian Penelitian ini dilakukan dua tahap :

I. Skala laboratorium, setiap $100 \mathrm{~g}$ feses dibiakkan dua ekor cacing dengan panjang yang relatif sama.

II. Skala lebih besar, feses dengan pertumbuhan cacing paling baik dipakai untuk pembiakan skala lebih besar agar didapat biomassa yang Iebih banyak untuk pakan. Perbandingan feces untuk media dengan cacing, yaitu $1 \mathrm{~kg}$ feces dibiakkan ke dalamnya $0,5 \quad \mathrm{~kg}$ cacing. 


\section{Hasil dan Pembahasan}

\section{Skala laboratorium}

P. excavatus dipelajari dalam batas skala labor, dengan empat macam feces murni dari empat jenis ternak. Penelitian dilakukan pada suhu $26{ }^{\circ} \mathrm{C}$ dan kelembaban $88 \%$. Dari pengamatan di lapangan didapat beberapa catatan penting :

- Feses segar, menyebabkan cacing kabur dan mati.

- Feses dipakai setelah didinginkan \pm 3 hari.

- Feses ayam tidak disukai cacing.

Media kering menyebabkan cacing tidak nyaman dan bergerak dan mencari tempat lain.

Tabel 1. Pengukuran Puhu dan $\mathrm{pH}$

\begin{tabular}{ccc}
\hline Feces & Suhu $\left({ }^{\circ} \mathbf{C}\right)$ & $\mathbf{p H}$ \\
\hline Sapi & 18,9 & 7,20 \\
Kuda & 21,1 & 7,83 \\
Kelinci & 20,5 & 7,57 \\
Ayam & 19,6 & 5,94 \\
\hline
\end{tabular}

Dari pengamatan dapat dilihat bahwa kondisi dan kandungan zat kimia dalam feses jelas berpengaruh. Kotoran yang baru diambil memiliki suhu yang beragam (tabel 1) namun masih berada dalam batas pertumbuhan normal cacing $P$. excavatus yaitu 18 - $30^{\circ} \mathrm{C}$. Kotoran sapi dan kelinci dikenal scbagai faces dingin karna fermentasi terjadi lama sehingga tidak menghasilkan amoniak dalam jumlah yang banak sehingga dalam tiga hari feces sudah bisa dikonsmsi oleh cacing. Sementara kotoran kuda dikenal dengan feces panas dimana amoniak terbentuk cepat dalam jumlah banyak sebagai akibat dari fermentasi yang berlangsung cepat.

Kandungan amoniak dalam feces memberikan suasana yang tidak nyaman terhadap cacing. Dalam perlakuan ekstrim cacing dibenamkan ke feces, bisa mengakibatkan kematian. Senyawa - senyawa dan materi sisa metabolisme juga menghasilkan $\mathrm{pH}$ yang beragam, dimana sangat mempengaruhi daya kosumtif $P$. excavatus.

Kotoran sapi memiliki $\mathrm{pH}$ normal, kotoran kelinci memiliki $\mathrm{pH}$ mendekati normal, sementara kotoran kuda memiliki $\mathrm{pH}$ yang sedikit basa dan kotoran ayam mcmiliki $\mathrm{pH}$ asam. Nilai $\mathrm{pH}$ kotoran sangat berperan terhadap kenyamanan makan cacing $P$. excavatus. Berdasarkan penelitian yang dilakukan oleh Shivri farm, cacing bisa bertahan hidup lebih lama pada media basa daripada media tanah yang diberi perlakuan kimia. Tiga kotoran pertama yaitu sapi, kelinci, dan kuda, cukup menarik bagi cacing. Ini terlihat dari keagresifan cacing begitu diletakan dalam baskom berisi kotoran tersebut. Pada kotoran ayam, cacing hanya menempatinya di hari pertama saja, untuk hari berikutnya cacing sudah bermigrasi ke tempat lain.

Kenyamanan cacing dalam media feces juga dipengaruhi oleh kelembaban media. Media feces yang hampir kering segera ditinggalkan cacing. Permukaan feces yang mengeras memberikan pengaruh negatif terhadap cacing. Jika terlalu banyak air pada feces juga menyebabkan cacing kabur karena kurangnya kantong udara untuk cacing. 
Pertumbuhan cacing $P$. excavatus dilihat dari pertambahan panjangnya. Kondisi yang sesuai akan menyebabkan cacing tumbuh dengan cepat dan bisa mencapai panjang maksimum $20 \mathrm{~cm}$ (penelitian terdahulu, gambar tidak ditampilkan). Pada penelitian ini pertambahan panjang cacing yang diukur seiap tiga hari, berkemungkinan dapat membuat cacing stres. Hal ini terlihat dari pertumbuhan yang lambat, dibandingkan dengan pertumbuhan cacing pada penelitian pendahuluan. Pertambahan panjang cacing $P$. excavatus dapat dilihat pada Tabel 2.

Di dalam Tabel 2 ini dapat dilihat bahwa pertumbuhan cacing pada feces sapi dan kelinci relatif sama (perbedaan $0,5 \mathrm{~cm}$ bisa diabaikan karena kontur tubuh cacing yang bersegmen segmen membuatnya susah diukur secara tepat dan konstan). Pertumbuhan yang relatif sama disebabkan oleh kondisi feces yang hampir sama yaitu suhu \pm $20{ }^{\circ} \mathrm{C}$ dan $\mathrm{pH}$ feses yang mendekati normal. Pada f-eses kuda, setelah hari ke 10 , cacing sudah tidak nyaman lagi dan bergerak ke tempat lain. Banyak faktor yang mempengaruhi diantaranya tersediaanya makanan (kotoran) yang lebih disukai di dekat medianya, kelembaban dan pH yang semakin tinggi (basa).

Pertumbuhan cacing $P$. excavatus juga diukur pertambahan berat badannya. Tetapi sifatnya relatif, karena cacing dengan panjang yang sama bisa berbeda beratnya tergantung jumlah mengkonsumsi makanan (Tabel 3). Cacing dengan panjang $6-8 \mathrm{~cm}$ memasuki masa dewasa. Cacing mulai kawin dan menghasilkan kokon.

Tabel 2. Pertumbuhan Cacing (panjang, $\mathrm{cm}$ )

\begin{tabular}{cccccccc}
\hline Feces & \multicolumn{7}{c}{ Hari } \\
\cline { 2 - 8 } & 1 & 4 & 7 & 10 & 13 & 16 & 19 \\
\hline \multirow{2}{*}{ Sapi } & 4,5 & 7,0 & 6,5 & 7,5 & 8,0 & 7,0 & 8,0 \\
\cline { 2 - 8 } & 4,0 & 6,5 & 5,0 & 5,0 & 7,0 & 7,0 & 7,5 \\
\hline \multirow{2}{*}{ Kuda } & 4,5 & 5,0 & 7,0 & 8,5 & - & - & - \\
\cline { 2 - 8 } & 4,5 & 4,5 & 5,0 & 7,0 & - & - & - \\
\hline \multirow{2}{*}{ Kelinci } & 4,5 & 6,0 & 6,5 & 7,0 & 7,0 & 6,0 & 8,0 \\
\cline { 2 - 8 } & 4,0 & 5,0 & 6,0 & 6,5 & 6,5 & 5,5 & 7,5 \\
\hline
\end{tabular}

Tabel 3. Pertumbuhan Cacing (berat, $\mathrm{mg}$ )

\begin{tabular}{cccccccc}
\hline Feces & \multicolumn{7}{c}{ Berat cacing $(\mathrm{mg})$} \\
\cline { 2 - 8 } & 1 & 4 & 7 & 10 & 13 & 16 & 19 \\
\hline \multirow{2}{*}{ Sapi } & 13,37 & 28,54 & 28,54 & 35,66 & 39,50 & 39,50 & 42,86 \\
\cline { 2 - 8 } & 12,76 & 20,77 & 20,77 & 28,34 & 28,54 & 29,10 & 33,22 \\
\hline \multirow{2}{*}{ Kuda } & 12,87 & 18,24 & 28,34 & 35,66 & - & - & - \\
& 13,37 & 13,37 & 18,24 & 26,74 & - & - & - \\
\hline \multirow{2}{*}{ Kelinci } & 13,37 & 19,38 & 26,74 & 33,32 & 35,67 & 35,66 & 39,50 \\
\cline { 2 - 8 } & 12,76 & 12,76 & 26,74 & 33,18 & 28,45 & 28,60 & 28,54 \\
\hline
\end{tabular}


Dari Tabel 2 dan Tabel 3 jelas terlihat bahwa pertumbuhan cacing pada feses kuda terganggu. Dengan kondisi $\mathrm{pH}$ yang semakin basa (Tabel 4) setelah penguraian oleh cacing dalam beberapa hari, membuat cacing pindah ke media lain. Naiknya nilai pH disebabkan oleh meningkatnya kandungan gugus fungsional $\mathrm{OH}$ atau basa lain seperti $\mathrm{NH}_{4}^{+}$. Pada Tabel 4 tidak tercantum pertumbuhan cacing pada feses ayam karena cacing segera bergerak pindah setelah dibiakkan di feses ayam yang memiliki $\mathrm{pH}$ asam. Derajat keasaman yang terlalu tinggi memberikan pengaruh negatif terhadap cacing dan sebaliknya, derajat keasaman yang rendah membuat rasa tidak nyaman pada makanan cacing.

Tabel 4. Suhu dan $\mathrm{pH}$ Terakhir

\begin{tabular}{lll}
\hline Kotoran & $\begin{array}{c}\text { Suhu } \\
\left({ }^{\circ} \mathrm{C}\right)\end{array}$ & $\mathrm{pH}$ \\
\hline Sapi & 20,3 & 7,20 \\
\hline Kuda & 20,2 & 8,34 \\
\hline Kelinci & 20,3 & 7,13 \\
\hline Ayam & 20,5 & 5,73 \\
\hline
\end{tabular}

Feses sapi dan kelinci yang telah diolah oleh cacing tidak mengalami perubahan suhu dan $\mathrm{pH}$ yang berarti. Kedua faktor ini mendekati normal, dan ini berarti menjelaskan suasana yang nyaman untuk tumbuhnva cacing. Berbeda halnya dengan feses kuda yang mengalami perubahan drastia pada $\mathrm{pH}$ menjadi basa dan suhu menjadi mendekati $2 \mathrm{O}^{\circ} \mathrm{C}$. Diduga telah terjadi proses fermentasi oleh mikroorganisme dalam feses kuda dengan cepat sehingga $\mathrm{pH}$ berubah.

Hasil kultur mikroorganis- me yang tumbuh dalam feses, juga mendukung hasil pengamatan di atas. Secara visual terlihat bahwa feses ayam, yang tidak disukai oleh cacing, teryata memiliki jenis mikroorganisme yang lebih banyak dibanding feses lain (Gambar 1).

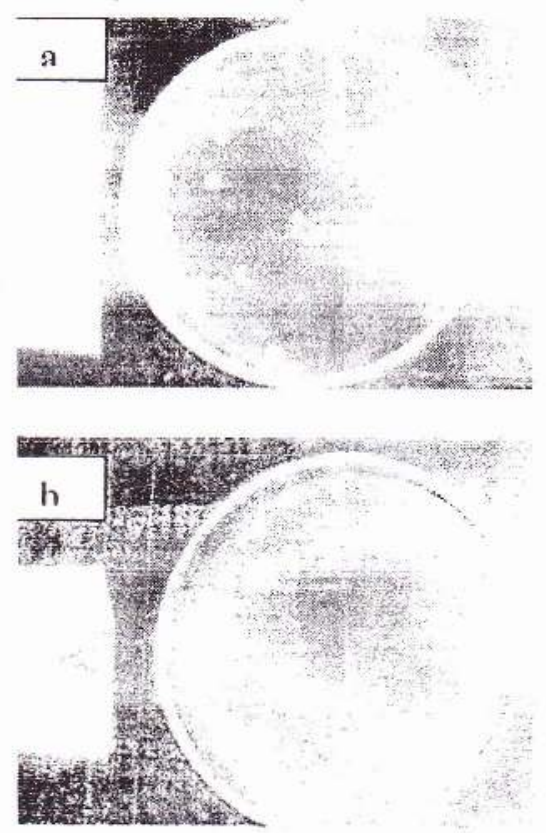

Gambar 1. Mikroorganisme pada feses sapi (a) dan ayam (b)

Kotoran ternak merupakan tempat tumbuh yang sangat baik bagi mikroorganisme. Secara alami jasad renik ini berperan dalam fermentasi bahan organik menjadi kompos. Dalam penelitian ini belum dilakukan isolasi dan identifikasi mikroorganisme.

II. Skala lebih besar (Vermikultur skala besar)

Pengamatan

- $1 \mathrm{~kg}$ feses sapi dipakai untuk: $0,5 \mathrm{~kg} P$. excavatus

- Feses diganti setiap 1 minggu.

- Cacing dewasa cepat beradaptasi dan mulai memasuki masa kawin (2 minggu pemeliharaan)

- $\quad$ Minggu ke 3 mulai mengandung 
- Kokon dan bertelur setelah \pm 15 hari.

- Tanah kascing yang berisi kokon

- Dipisahkan dari biomassa dan dibiarkan selama 1 minggu

- Bayi - bayi cacing mulai menetas, dengan panjang \pm 2 $\mathrm{cm}$, dihitung sebagai panjang awal pengamatan.

Bayi cacing ditumbuhkan dalam kotoran sapi, dan diamati pertumbuhannya dan reproduksinya. Uraian pertumbuhan cacing dapat dilihat dalam Tabel 5.

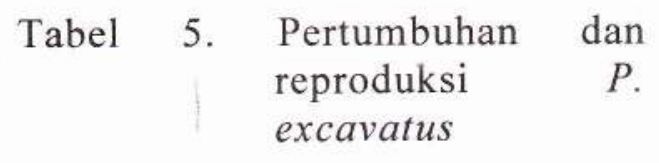

\begin{tabular}{cl}
\hline Hari & \multicolumn{1}{c}{ Fisiologi Cacing } \\
\hline 0 & Bayi cacing \\
5 & Anak cacing $(4 \mathrm{~cm})$ \\
10 & $\begin{array}{l}\text { Cacing mulai dewasa }(6 \\
\mathrm{cm})\end{array}$ \\
15 & Cacing dewasa $\quad(8 \mathrm{~cm})$ \\
\hline
\end{tabular}

Pertumbuhan berikutnya dihitung sebagai pertumbuhan skala besar. Cacing dibiakkan dalam media feses sapi. Cacing dewasa cepat beradaptasi dan memasuki masa kawin, mengandung kokon, bertelur dan menetas. Cacing membutuhkan waktu untuk bereproduksi lebih kurang selama 1 bulan dan masa penetasan serta pendewasaan $3-4$ minggu. Jadi dengan pembiakan awal $1 \mathrm{~kg}$ cacing dewasa, pada 2 bulan berikutnya biomassa sudah menjadi $2 \mathrm{~kg}$.

Kascing yang dihasilkan dari vermiukultur ini ternyata memiliki tekstur yang bagus yaitu : berbentuk granula kecil - kecil dengan kondisi :

- lembab

- Porositas tinggi

- $\mathrm{pH}$ netral

- kandungan unsur hara tinggi

Tanah subur secara alami disebabkan oleh adanya humus. Pada hakekatnya humus adalah bahanbahan organik seperti daun dan buah yang jatuh ke tanah dan oleh mikroorganisme tanah dikonversi menjadi subur. Pupuk tanah atau pupuk organik sangat berperan dalam memperbaiki sifat-sifat fisik tanah, yaitu memperbaiki struktur tanah, daya meresapkan air hujan, daya mengikat air, tata udara tanah, ketahanan terhadap erosi dan lainlain. Susunan maupun nilai unsur hara dari pupuk kandang adalah berbeda-beda. Faktor - faktor yang mempengaruhi susunan dan nilai pupuk kandang adalah: jenis hewan, umur hewan, kualitas makanan hewan, jumlah dan jenis alas kandang, dan cara menyimpan.

\section{Kesimpulan}

- Cacing tanah P. excavatus dapat menguraikan kotoran ternak dengan cepat .

- Tingkat penguraian secara berurutan

- F.sapi $\geq$ f.kelinci $>$ f. kuda

- Feses ayam tidak cocok untuk MO ini

- Pupuk kandang yang dihasilkan memiliki mutu yang lebih baik dari pada yang dikeringkan biasa.

\section{Daftar Pustaka}

Anderson. R.S., (1988). Bacteriostatic Faktor(s) in the coelomic fluid of Lumbricus terrestris. Dev. Comp. Immum. 
12. 189-194.

Baier. K.S., and McClements, D.J., (2005). Influence of cosolvent systems on the gelation mechanism of globular protein : thermodynamic. kinetic. and structural aspects of globular protein gelation. Comp. Reviews in Fond Science and Food Safety. 4. 43 - 53

Bauer. A.W., Kirby, W.M.N., Sherris, J.C., Turck.M., (1966) Antibiotic susceptibility testing by standardized single disk method. Am. J. Clin.Pathol. 45. 493 - 496.

Blakemore. R., (2001). Tasmanian earthworm grows second head. Invertebrata. 20.

Cassell. G.H., and Mekalanos. (2001). Development of antimicrobial agents in the era of new and reemerging infectious deseases and increasing antibitic resistance., JAMA. 285, 601 - 605 .

Chauduri. P.S., and Bhattacharjee. G., (2002). Capacity of various experimental diets to support biomass and reproduction of Perionyx excavatus. Bioresource Technol. 82(2). 147-150.

Cho..JH., Park. C.B., Yoon, G.Y., Kim, S.C., (1995). Lumbricin I, a novel prolin-rich antimicrobial peptide from the earthworm : purification, cDNA cloning and molecular characterization. Biophys. Acta. 1408. 67-76.
Cho, J.H Choi, E.S., and Lee, H.H., (2004). Molecular cloning, sequencing and expression of a fibrinolytic serine-protease gene from the earthworm L. terrestris. J.Biochem.Mol. Biol, 37(5), 574-551.

Cooper, E.L., and Roch. P., (2003), Earthworm immunity a model of immune competence. Pedobiologia. 47.

Cooper. E. L., Kauschke. E., and Cossarizza, A., (2002). Digging for innate immunity since Darwin and Metchnikoff. Bioassays. 24(4). 319-333

Dhainaut, A., Scaps. P., (2001). Immune defense and biological responses induced by toxics in annelida. Can. J. Zoo./Ref: Can. Zoo. 79(2). 233-253

Dong.G.Q., et.al., (2004). Molecular cloning and Characterization of cDNA encoding Fibrinolytic enzyme-3, from earthworm Eisenia foetida. Biochem. Biophys.Acta sinica 36(4). 303-308.

Edwar. C.A.. Dominguez. J., Neunauser. E.F., (1998). (Growth and reproduction of Perionyx excavatus (Perr.) (Megascolecidae ) as factor in organic waste management. Biol. Fertil Soil 27. 155-161

Engelmann. P., Kiss. J., Csongei. V.., Cooper. E.L., Nemeth, P., (2004). Earthworm leukocytes kill HeLa, Hep-2, PC-12 and PA317 cells in Vitro., J. Biochem. Biophys. Methodes 61. 215-227. 
Engelmann, P., Molnar. L., Palinkas. L.. Cooper. E.L., (2004). Earthworm leukocytes populations specifically harbor lysosomal enzyme that may respond to bacterial challege. Cell Tissue res., 316. 319-401.
Eue. ., Kauschke. E., Mohrig. W., and Cooper. E.L., (1998). Isolation and characterization of earthworm hemolysins and agglutinins. Dev. Comp. Immun. 22 (1). 13-25.

Alamat korespondensi : Yumaihana, S.Si, M.Si

Jurusan Nutrisi dan Makanan Ternak

Fakultas Peternakan Universitas Andalas

Padang

Diterima: 30 April 2007, Disetujui: 22 Mei 2007 